\title{
Toxicological Effects, Prophylactic and Curative Activity of Rauwolfia vomitoria Leaf Extracts on Plasmodium Berghei NK 65 infected Swiss albino mice
}

\author{
Omoya Funmilola Oluyemi* and Falusi Olatunde Ademoye \\ Department of Microbiology, The Federal University of Technology, Nigeria \\ *Corresponding author: Omoya Funmilola Oluyemi, Department of Microbiology, The Federal University of Technology, Nigeria. \\ To Cite This Article: Omoya Funmilola Oluyemi. Toxicological Effects, Prophylactic and Curative Activity of Rauwolfia vomitoria Leaf Extracts \\ on Plasmodium Berghei NK 65 infected Swiss albino mice. Am J Biomed Sci \& Res. 2019 - 3(6). AJBSR.MS.ID.000730. \\ DOI: 10.34297/AJBSR.2019.03.000730
}

Received: June 06, 2019 | Published: July 10, 2019

\begin{abstract}
This study evaluates prophylactic and curative antiplasmodial effects of Rauwolfia vomitoria leaf extracts on Plasmodium berghei NK 65. The extracts of the leaves at 100, 200 and $400 \mathrm{mg} \mathrm{kg}-1$ body weight/day dose levels were used to treat the test groups 72 hours before infection for the prophylactic test and 72 hours post infection for the curative test while a standard antimalarial drug, chloroquine, at a dose of 5 mg kg-1 body weight was administered on the positive control group. The negative control groups were left untreated. The level of parasitemia, Percentage Packed Cell Volume (\% PCV), erythrocytes (RBC) and leukocytes (WBC) counts in the different groups were monitored also, bicarbonate, creatinine, uric acid, urea, calcium level and histological effects of extracts were determined during the period of study. Qualitative and quantitative phytochemicals of water and ethanol leaf extracts were determined. The water and ethanol crude extract at $400 \mathrm{mg} \mathrm{kg-1}$ body weight/day had chemo-suppression of 95.27 and $97.21 \%$ for prophylactic test as against $81.88 \%$ for the standard drug while the level of parasitemia was reduced by 80.91 and $87.64 \%$ respectively after treating for five days in the curative test as against $88.98 \%$ for the standard drug. The variations in the values of Percentage Packed Cell Volume (\%PCV), erythrocyte counts, bicarbonate, creatinine, uric acid, urea and calcium level for groups treated with water and ethanol extracts were significant $(\mathrm{p}<0.05)$ for prophylactic and curative treatment. Histological features revealed that there were well-formed liver hepatocytes with minor injury in ethanol extract when used as prophylactic treatment. Alkaloid, Anthraquinones, Cardenoloides, Glycosides, Phenol, Phlobatanin, Reserpine, Resins and Saponin were present in the crude extract. The result of this study suggests that extracts of $R$. vomtitoria has antiplasmodial effects, these however supports local claims on the efficacy of the plant's leaf in the treatment malarial infections. This study has implications in future development of antimalarial drugs with little or no cytotoxic effect.
\end{abstract}

Keywords: Chemo-suppression; Prophylactic; Curative; Extracts; Phytochemicals

\section{Introduction}

Ethno botany is the use of plants by humans traditionally; a science, which include a study of the plants used tribally for food, medicine and clothing [1] and it is an effective way to the discovery of future medicine [2]. The world health organization (WHO) estimates that $80 \%$ of some Asian and African countries use herbal medicines for some aspect of primary health care although orthodox medicines are readily available, a large percentage of the population still use herbal remedies along with or in preference to conventional medicines [3]. African medicinal plants have demonstrated diverse potentials as possible sources of promising antibacterial and antiplasmodial compounds that are accessible, cheap, affordable, available and sustainable [4-6]. Rauwolfia vomitoria Afzel (Apocynaceae) is a small shrub evergreen perennial plant, which grows to $15 \mathrm{~m}$ high and has oval or oblong shiny leaves in whorls, straight veining and a cluster of inconspicuous white or greenish flowers producing red berries [7]. It grows in most tropical forest of pacific, South America, Asia and Africa. In Ghana and Nigeria Rauwolfia vomitoria is used traditionally against snake bites, malaria, fever and nervous disorders as well as emetic and purgative [8]. R. vomitoria are also used in the treatment of cerebral cramps, jaundice and gastrointestinal disorders in children [9]. The watery solution of the bark of $R$. vomitoria can be used against parasites such as lice and scabies [10]. In Mali, the roots of Rauwolfia have been use in the treatment of hemorrhoids and hepatomegaly [11]. 


\section{Materials and Method}

\section{Source and Identification of Plant Leaf}

$R$. vomitoria leaves were collected from North gate area of The Federal University of Technology, Akure, Ondo State. The leaf were collected before the sunrise to prevent plant photo-oxidation, the leaf that has no injury nor chlorosis were sorted out and kept in a clean sack for further work. The plant (commonly referred to as Asofeyeje (Yoruba) and was authenticated by plant scientist at the Federal University of Technology, Department of Crop Science and Pest management.

\section{Processing and Extraction of Rauwolfia vomitoria Leaves}

Method of [12] was used for the processing and extraction of Rauwolfia vomitoria using ethanol and hot water as extraction solvent. The extracts were preserved in a sterile bottle at $4^{\circ} \mathrm{C}$ ready for use.

\section{Experimental Mice}

The experimental mice were obtained from the school of biological science, Afe-Babalola University, Ado-Ekiti. During the acclimatization period (14 days), all mice were fed with water and commercial feed under standard conditions according to [13]. They weigh between 19-23g and were all male.

\section{Infection of Experimental Mice}

The mice were carefully infected intraperitonially with $0.2 \mathrm{ml}$ of $1.67 \times 10^{6}$ parasitised red blood cell of Plasmodium berghei NK 65 obtained from Nigeria Institute of Medical Research (NIMR), Yaba, Lagos.

\section{Parasitemia Count}

The parasitemia count was carried out daily starting from after the first oral treatment. This was carried out by a little cut on their tail and making a smear of the blood on the slide.

$$
\begin{gathered}
\% \text { Parasitaemia }=\frac{\text { total number of Parasitized red blood cells }}{\text { total } \text { number of red blood cells }} \times 100 \\
\text { \%chemo }- \text { suppression }=\frac{(\text { Parasitaemia in control group-parasitaemia in study group) } \times 100}{\text { Parasitaemia in control group }} \\
\text { Experimental Design }
\end{gathered}
$$

Group A- Infected and treated with $100 \mathrm{mg} / \mathrm{kg} \mathrm{R}$. vomitoria of ethanol extract.

Group B- Infected and treated with $200 \mathrm{mg} / \mathrm{kg} \mathrm{R}$. vomitoria of ethanol extract.

Group C- Infected and treated with $400 \mathrm{mg} / \mathrm{kg} \mathrm{R}$. vomitoria of ethanol extract.

Group D- Infected and treated with $100 \mathrm{mg} / \mathrm{kg} \mathrm{R}$. vomitoria of hot water extract.

Group E- Infected and treated with $200 \mathrm{mg} / \mathrm{kg} \mathrm{R}$. vomitoria of hot water extract.

Group F- Infected and treated with $400 \mathrm{mg} / \mathrm{kg} R$. vomitoria of hot water extract.

Group G- Infected and treated with 5mg/kg chloroquine.
Group H- Infected and treated with $0.2 \mathrm{mls}$ of distilled water.

Antiplasmodial Prophylactic Activity of R. serpentina Leaf Extracts of Mice Infected with Plasmodium berghei

Prophylactic activity was tested using the procedure described by [14]. Mice in group A-F were treated with graded dose of extracts, group $\mathrm{G}$ and $\mathrm{H}$ received $5 \mathrm{mg} / \mathrm{kg}$ of chloroquine (positive control) and $0.2 \mathrm{ml}$ of normal saline (negative control) for 3 days after which the mice were inoculated with Plasmodium berghei.

Antiplasmodial Curative Activity of R. serpentina Leaf Extracts on Mice Infected with Plasmodium berghei

Curative assay was carried out by inoculating each mouse in the 14 groups with the parasite intraperitonally and left for 72 hours ( 3 days) to achieve parasitemia count of 100,000 parasites/ $\mu$ l. Mice in group A-F were treated orogastric ally with plant extracts at different concentrations $(100,200$ and $400 \mathrm{mg} / \mathrm{kg}$ ) while mice in the positive (Group $\mathrm{G}$ ) and negative control $(\mathrm{H})$ group were treated with $5 \mathrm{mg} / \mathrm{kg}$ chloroquine and $0.2 \mathrm{mls}$ of distilled water respectively for 5 days [15].

\section{Phytochemical Screening}

The phytochemical analysis was carried out according to the standard methods of analysis by [16].

\section{Tests for Organ function indices}

Biochemical tests for determination of bicarbonate, creatinine, calcium, uric acid and urea level were done according to [17].

\section{Collection of Liver from Experimental mice and Histopathological Test}

For histopathological assays, the liver was dissected out using clean dissecting tools and collected into specimen bottles containing $10 \%$ formalin according to standard method by [17]. Histopathological test on the liver was performed according to the method of [17] and [18].

\section{Statistical Analysis of Result}

Result obtained were subjected to descriptive statistics and one way Analysis of Variance (ANOVA), means were separated by new Duncan Multiple Range and significant level was taken at $(\mathrm{p}<0.05)$ using SPSS version 20 Microsoft windows 8 .

\section{Results}

\section{Percentage Yield of Plant Extracts}

Table 1: Percentage (\%) yield of crude extracts obtained from leaves powders of R. serpentina and R. vomitoria.

\begin{tabular}{|c|c|c|c|}
\hline Plants / Solvents & $\begin{array}{c}\text { Weight of } \\
\text { Plants Used } \\
\text { (grams) }\end{array}$ & Yields (grams) & $\begin{array}{c}\text { Percentage } \\
\text { Yield (\%) }\end{array}$ \\
\hline RVW & 200 & 13.6 & 6.8 \\
\hline RVE & 200 & 20.4 & 10.2 \\
\hline
\end{tabular}

Note: Keys: RVW= R. vomitoria water extract, RVE= R. vomitoria ethanol extract. 
The results shown in Table 1 revealed the percentage yield of plant extracts. The ethanol extract of $R$. vomitoria yielded $10.2 \%$ while the hot water extract had $6.8 \%$ yields.

\section{Qualitative Phytochemical Compositions of R. Vomitoria Extracts}

The result of $R$. Vomitoria extracts qualitative phytochemical compositions are shown in Table 2 . The result showed that alkaloid, anthraquinones, cardenoloides, glycosides, phenol, phlobatanin, resin and saponin were present in hot water and ethanol extract of the plant, however, ajimaline was absent.

Table 2: Results Qualitative phytochemicals of $R$. vomitoria leaf extracts.

\begin{tabular}{|c|c|c|}
\hline Phytochemicals & RVW & RVE \\
\hline Ajimaline & - & + \\
\hline Alkaloid & + & + \\
\hline Anthraquinones & + & + \\
\hline Cardenoloides & + & + \\
\hline Glycosides & + & + \\
\hline Phenol & + & + \\
\hline Phlobatanin & + & + \\
\hline Reserpine & + & + \\
\hline Resins & + & + \\
\hline Saponin & + \\
\hline
\end{tabular}

Note: Keys: RVW: R. vomitoria water extract; RVE: R. vomitoria ethanol extract; += present, $-=$ absent.

\section{Quantitative Phytochemical Compositions of R.} Vomitoria Extracts

\begin{tabular}{|c|c|c|}
\hline Phytochemicals & RVW (mg/g) & RVE (mg/g) \\
\hline Ajmaline & $0.000 \pm 0.000^{\mathrm{a}}$ & $0.096 \pm 0.030^{\mathrm{a}}$ \\
\hline Alkaloid & $0.100 \pm 0.012^{\mathrm{ab}}$ & $0.204 \pm 0.030^{c}$ \\
\hline Anthraquinones & $0.296 \pm 0.003^{c}$ & $0.101 \pm 0.002^{\mathrm{b}}$ \\
\hline Cardenoloides & $0.077 \pm 0.010^{\mathrm{ab}}$ & $0.069 \pm 0.003^{\mathrm{a}}$ \\
\hline Glycosides & $0.032 \pm 0.002^{\mathrm{a}}$ & $0.044 \pm 0.104^{\mathrm{ab}}$ \\
\hline Phenol & $0.166 \pm 0.003^{c}$ & $0.101 \pm 0.004^{\mathrm{b}}$ \\
\hline Phlobatanin & $0.122 \pm 0.022^{\mathrm{c}}$ & $0.120 \pm 0.010^{c}$ \\
\hline Reserpine & $0.084 \pm 0.001^{c}$ & $0.204 \pm 0.003^{\mathrm{d}}$ \\
\hline Resins & $0.012 \pm 0.001^{\mathrm{a}}$ & $0.080 \pm 0.002^{\mathrm{bc}}$ \\
\hline Saponin & $0.110 \pm 0.001^{\mathrm{b}}$ & $0.092 \pm 0.201^{\mathrm{a}}$ \\
\hline
\end{tabular}

Note: Values are presented as Mean \pm SEM, Values in the same column followed by the same letter do not differ significantly $(p \geq 0.05)$ according to new Duncan's Multiple Range test. Keys: RVW: $R$. vomitoria water extract; RVE: R. vomitoria ethanol extract.

Table 3 showed that water extract of the plant had the highest anthraquinones composition of $0.296 \pm 0.003 \mathrm{mg} / \mathrm{g}$ followed by ethanol extract of reserpine and alkaloid composition of $0.204 \pm 0.003$ and $0.204 \pm 0.030 \mathrm{mg} / \mathrm{g}$. Resin had the lowest composition of water extract $(0.012 \pm 0.001 \mathrm{mg} / \mathrm{g})$ while the lowest composition of the ethanol extract was found in Cardenoloides of $0.069 \pm 0.003 \mathrm{mg} / \mathrm{g}$.

\section{Prophylactic effect of ethanol and water leaves extract} of $R$. vomitoria leaf extracts in $P$. berghei infected mice

\begin{tabular}{|c|c|c|c|c|}
\hline \multirow{2}{*}{$\begin{array}{l}\text { Ex- } \\
\text { tracts }\end{array}$} & \multirow{2}{*}{ Group } & \multirow{2}{*}{$\begin{array}{l}\text { Doses } \\
\mathrm{mg} / \mathrm{kg}\end{array}$} & $\begin{array}{c}\text { Average Parasite- } \\
\text { mia }\end{array}$ & \multirow{2}{*}{$\begin{array}{c}\% \text { chemo suppres } \\
\text { sion }\end{array}$} \\
\hline & & & (parasite/ $/ \mu$ ) & \\
\hline \multirow[t]{3}{*}{$\begin{array}{c}\text { Etha- } \\
\text { nol }\end{array}$} & A & 100 & $4642.25 \pm 289.73$ & 90.81 \\
\hline & B & 200 & $2288.25 \pm 174.40$ & 95.47 \\
\hline & $\mathrm{C}$ & 400 & $1411.00 \pm 201.49$ & 97.21 \\
\hline \multirow[t]{3}{*}{ Water } & $\mathrm{D}$ & 100 & $9676.50 \pm 1984.55$ & 80.84 \\
\hline & $\mathrm{E}$ & 200 & $4726.50 \pm 881.34$ & 90.64 \\
\hline & $\mathrm{F}$ & 400 & $2387.75 \pm 320.41$ & 95.27 \\
\hline PC & G & 5 & $9150.00 \pm 1621.47$ & 81.88 \\
\hline $\mathrm{NC}$ & $\mathrm{H}$ & 5 & $50500.00 \pm 5484.83$ & \\
\hline
\end{tabular}

Note: NC: Negative Control (distilled water); PC: Positive Control (Chloroquine).

The result of the prophylactic treatment as showed in Table 4 revealed that the chemo-suppressive activity increases as the dose of plants' extract increases. The chemo-suppressive activity of $R$. vomitoria ethanol extract at 100, 200 and $400 \mathrm{mg} / \mathrm{kg}$ body weight was $90.72,95.57$ and $97.72 \%$ respectively while the water extract at 100,200 and $400 \mathrm{mg} / \mathrm{kg}$ had 80.84, 90.64 and $95.27 \%$.

Curative effect of ethanol and water leaves extract of $\mathbf{R}$. serpentina and $R$. vomitoria leaf extracts in $P$. berghei infected mice

Table 5: Curative Effect of Ethanol and Water Leaves Extract of $R$. vomitoria in $P$. berghei infected mice.

\begin{tabular}{|c|c|c|c|c|}
\hline \multirow{2}{*}{$\begin{array}{l}\text { Ex- } \\
\text { tracts }\end{array}$} & \multirow{2}{*}{ Group } & \multirow{2}{*}{$\begin{array}{c}\text { Doses mg/ } \\
\text { kg }\end{array}$} & Average Parasitemia & \multirow{2}{*}{$\begin{array}{l}\text { \% chemo } \\
\text { suppression }\end{array}$} \\
\hline & & & (parasite $/ \mu \mathrm{l})$ & \\
\hline \multirow[t]{3}{*}{$\begin{array}{c}\text { Etha- } \\
\text { nol }\end{array}$} & A & 100 & $19962.20 \pm 1822.60$ & 76.51 \\
\hline & B & 200 & $13578.60 \pm 2404.22$ & 84.02 \\
\hline & $\mathrm{C}$ & 400 & $10499.00 \pm 2962.19$ & 87.64 \\
\hline \multirow[t]{3}{*}{ Water } & $\mathrm{D}$ & 100 & $26757.40 \pm 1351.68$ & 68.51 \\
\hline & $\mathrm{E}$ & 200 & $19802.00 \pm 715.18$ & 76.69 \\
\hline & $\mathrm{F}$ & 400 & $16221.80 \pm 1703.86$ & 80.91 \\
\hline PC & G & 5 & $9366.75 \pm 424.46$ & 88.98 \\
\hline $\mathrm{NC}$ & $\mathrm{H}$ & 5 & $84971.50 \pm 1906.80$ & \\
\hline
\end{tabular}

Note: NC: Negative Control (distilled water); PC: Positive Control (Chloroquine). 
It was observed that the chemo-suppressive activity result of curative treatment as shown in Table 5 was dose dependent. At 100, 200 and $400 \mathrm{mg} / \mathrm{kg}$ body weight of $R$. vomitoria ethanol extract, the chemo-suppressive rate was noted at $76.51,84.02$ and 87.64
$\%$ respectively while the highest chemo-suppressive rate observed in water extract was $80.91 \%$ in the mice treated with $400 \mathrm{mg} / \mathrm{kg}$ body weight after 5 days of treatment.

Effect of Curative treatment on organ function indices (Biochemical) in mice treated with extracts of R. vomitoria

\begin{tabular}{|c|c|c|c|c|c|}
\hline \multirow{2}{*}{ Groups } & \multirow{2}{*}{ BC (mMol/L) } & CR & UA & $\mathbf{U}$ & CA \\
\hline & & $(\mathrm{mMol} / \mathrm{L})$ & $(\mathrm{mMol} / \mathrm{L})$ & $(\mathrm{mMol} / \mathrm{L})$ & $(\mathrm{mMol} / \mathrm{L})$ \\
\hline A & $12.00 \pm 2.00^{\mathrm{a}}$ & $0.20 \pm 0.03^{\mathrm{de}}$ & $0.40 \pm 0.17^{\mathrm{abc}}$ & $4.47 \pm 0.18^{\mathrm{cd}}$ & $4.63 \pm 0.15^{\text {de }}$ \\
\hline B & $25.00 \pm 2.65^{\mathrm{cd}}$ & $0.07 \pm 0.00^{\mathrm{a}}$ & $0.39 \pm 0.02^{\mathrm{abc}}$ & $4.50 \pm 0.21^{\mathrm{cd}}$ & $2.67 \pm 0.12^{\mathrm{ab}}$ \\
\hline $\mathrm{C}$ & $42.33 \pm 2.85^{\mathrm{f}}$ & $0.41 \pm 0.02^{\mathrm{f}}$ & $0.44 \pm 0.02^{\mathrm{abc}}$ & $5.47 \pm 0.35^{\mathrm{fg}}$ & $4.27 \pm 0.18^{\mathrm{d}}$ \\
\hline D & $16.33 \pm 0.88^{\mathrm{ab}}$ & $0.12 \pm 0.02^{\mathrm{abc}}$ & $0.39 \pm 0.02^{\mathrm{abc}}$ & $4.50 \pm 0.10^{\mathrm{cd}}$ & $5.10 \pm 0.15^{\text {ef }}$ \\
\hline $\mathrm{E}$ & $25.33 \pm 0.33^{\text {cd }}$ & $0.09 \pm 0.01^{\mathrm{ab}}$ & $0.30 \pm 0.02^{\mathrm{a}}$ & $4.37 \pm 0.27^{\mathrm{bcd}}$ & $2.60 \pm 0.15^{\mathrm{a}}$ \\
\hline $\mathrm{F}$ & $31.00 \pm 1.00^{\mathrm{e}}$ & $0.23 \pm 0.02^{\mathrm{e}}$ & $0.35 \pm 0.03^{\mathrm{ab}}$ & $4.53 \pm 0.18^{\mathrm{cd}}$ & $2.93 \pm 0.13^{\mathrm{ab}}$ \\
\hline G & $31.33 \pm 1.45^{\mathrm{e}}$ & $0.06 \pm 0.00^{\mathrm{a}}$ & $0.49 \pm 0.01^{\text {bcd }}$ & $4.23 \pm 0.02^{\mathrm{abcd}}$ & $2.53 \pm 0.12^{\mathrm{a}}$ \\
\hline $\mathrm{H}$ & $51.33 \pm 1.20^{\mathrm{g}}$ & $1.19 \pm 0.05^{g}$ & $0.64 \pm 0.03^{\mathrm{d}}$ & $5.93 \pm 0.04 \mathrm{~g}$ & $5.37 \pm 0.15^{\mathrm{f}}$ \\
\hline indard value & Oct-35 & $0.05-0.15$ & $0.2-0.5$ & $2.5-5.0$ & $2.5-4.0$ \\
\hline
\end{tabular}

Note: Values are presented as Mean \pm SEM, Values in the same column followed by the same letter do not differ significantly $(p \geq 0.05)$ according to New Duncan's Multiple Range test. Keys: A= RVE 100mg/kg; B=RVE 200mg/kg; C=RVE 400mg/kg; D= RVW 100mg/kg; E= RVW 200mg/kg; $\mathrm{F}=\mathrm{RVW} 400 \mathrm{mg} / \mathrm{kg} ; \mathrm{G}=\mathrm{PC}$ : Positive Control (treated with $5 \mathrm{mg} / \mathrm{kg}$ Chloroquine); $\mathrm{H}=\mathrm{NC}$ : Negative Control (infected treated with distilled water), BC: Biocarbonate; CR: Creatinine; UA: Uric Acid; U: Urea; CA: Calcium.

Standard Value's Source: [19][20][21].

The curative result of the biochemical assay as showed in Table 6 revealed that the treated group significantly $(\mathrm{p}<0.05)$ decreased the biochemical parameters at100 and $200 \mathrm{mg} / \mathrm{kg}$ concentration and at a higher concentration $(400 \mathrm{mg} / \mathrm{kg})$ increased some parameters compared with the standard range of organ function indices. The least significant $(\mathrm{p}<0.05)$ decrease was observed at $100 \mathrm{mg} / \mathrm{kg}$ ethanol extract for Biocarbonate $(12.00 \pm 2.00 \mathrm{mMol} / \mathrm{L})$. At $400 \mathrm{mg} / \mathrm{kg}$ water extract, biocarbonate and urea had the highest significant $(\mathrm{p}<0.05)$ increase of $42.44 \pm 2.85$ and $5.47 \pm 0.35 \mathrm{mMol} / \mathrm{L}$.

Effect of Prophylactic Treatment on Organ Function Indices (Biochemical) in Mice Treated with Extracts of R. vomitoria

\begin{tabular}{|c|c|c|c|c|c|}
\hline \multirow{2}{*}{ Groups } & BC & CR & UA & $\mathbf{U}$ & CA \\
\hline & $(\mathrm{mMol} / \mathrm{L})$ & (mMol/L) & $(\mathrm{mMol} / \mathrm{L})$ & (mMol/L) & $(\mathrm{mMol} / \mathrm{L})$ \\
\hline A & $22.00 \pm 2.00^{\mathrm{abc}}$ & $0.16 \pm 0.02^{\mathrm{b}}$ & $0.52 \pm 0.06^{\text {def }}$ & $3.80 \pm 0.35^{\mathrm{ab}}$ & $4.37 \pm 0.18^{\mathrm{d}}$ \\
\hline B & $23.00 \pm 1.73^{\mathrm{bc}}$ & $0.07 \pm 0.06^{\mathrm{a}}$ & $0.85 \pm 0.03^{g}$ & $4.63 \pm 0.26^{\text {cd }}$ & $4.20 \pm 0.35^{\mathrm{cd}}$ \\
\hline $\mathrm{C}$ & $52.33 \pm 2.85^{\mathrm{f}}$ & $0.55 \pm 0.03^{\mathrm{e}}$ & $0.39 \pm 0.01^{\mathrm{bcd}}$ & $6.40 \pm 0.20^{\mathrm{f}}$ & $5.17 \pm 0.23^{\mathrm{ef}}$ \\
\hline $\mathrm{D}$ & $22.00 \pm 2.31^{\mathrm{abc}}$ & $0.15 \pm 0.02^{\mathrm{b}}$ & $0.34 \pm 0.03^{\mathrm{ab}}$ & $3.93 \pm 0.33^{\mathrm{bc}}$ & $4.83 \pm 0.07^{\text {def }}$ \\
\hline E & $30.00 \pm 1.15^{\mathrm{d}}$ & $0.11 \pm 0.01^{\mathrm{ab}}$ & $0.65 \pm 0.09^{\mathrm{f}}$ & $5.03 \pm 0.12^{\mathrm{de}}$ & $3.65 \pm 0.32^{\mathrm{bc}}$ \\
\hline $\mathrm{F}$ & $41.00 \pm 2.00^{\mathrm{e}}$ & $0.35 \pm 0.02^{\mathrm{d}}$ & $0.36 \pm 0.02^{\mathrm{abc}}$ & $5.70 \pm 0.40^{\mathrm{ef}}$ & $3.43 \pm 0.19^{\mathrm{b}}$ \\
\hline G & $31.33 \pm 1.45^{\mathrm{d}}$ & $0.06 \pm 0.00^{\mathrm{a}}$ & $0.49 \pm 0.01^{\text {bcde }}$ & $4.23 \pm 0.02^{\mathrm{bc}}$ & $2.53 \pm 0.12^{\mathrm{a}}$ \\
\hline $\mathrm{H}$ & $51.33 \pm 1.20^{\mathrm{f}}$ & $1.19 \pm 0.05^{\mathrm{f}}$ & $0.64 \pm 0.03^{f}$ & $5.93 \pm 0.03^{f}$ & $5.37 \pm 0.15^{f}$ \\
\hline $\begin{array}{l}\text { Standard } \\
\text { value }\end{array}$ & Oct-35 & $0.05-0.15$ & $0.2-0.5$ & $2.5-5.0$ & $2.5-4.0$ \\
\hline
\end{tabular}

Note: Values are presented as Mean \pm SEM, Values in the same column followed by the same letter do not differ significantly $(p \geq 0.05)$ according to New Duncan's Multiple Range test. Keys: A= RVE 100mg/kg; B= RVE 200mg/kg; C= RVE 400mg/kg; D= RVW 100mg/kg; E= RVW 200mg/kg; $\mathrm{F}=\mathrm{RVW} 400 \mathrm{mg} / \mathrm{kg} ; \mathrm{G}=\mathrm{PC}$ : Positive Control (treated with $5 \mathrm{mg} / \mathrm{kg}$ Chloroquine); $\mathrm{H}=\mathrm{NC}$ : Negative Control (infected treated with distilled water); BC: Biocarbonate; CR: Creatinine; UA: Uric Acid; U: Urea; CA: Calcium. Standard Value's Source: [19-21].

The result of the prophylactic biochemical assay of mice treated with plant extracts (Table 7) showed that at different concentrations there was significant $(p<0.05)$ decrease and increase in the parameters of the treated groups of mice compared with the standard values of healthy mice. There was significant $(p<0.05)$ increase in uric acid. At $200 \mathrm{mg} / \mathrm{kg}$ ethanol extract, calcium 
$(3.03 \pm 0.12 \mathrm{mMol} / \mathrm{L})$, at $400 \mathrm{mg} / \mathrm{kg}$ water extract, creatinine, urea and calcium had the highest significant $(p<0.05)$ increase of $0.55 \pm 0.03,6.40 \pm 0.20$ and $5.17 \pm 0.2315 \mathrm{mMol} / \mathrm{L}$ respectively (Figures $1 \& 2$ ).

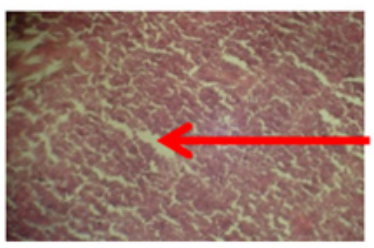

Well-formed liver hepatocytes with little disjointed cells.

A

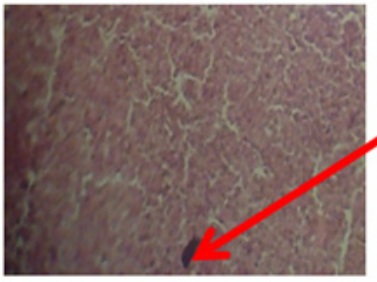

Well-

formed liver hepatocytes showing

light fibrous tissues

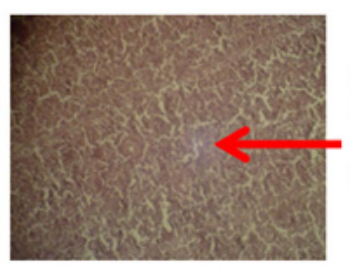

Formed liver hepatocytes

that have

haemolysis

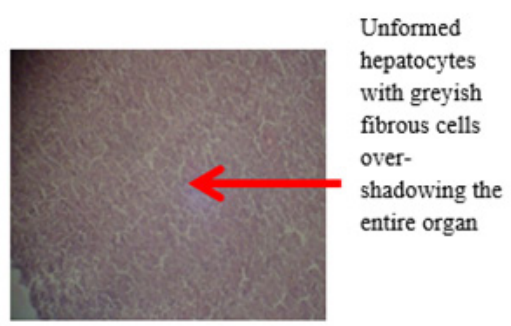

Note: Keys: $\mathrm{A}=200 \mathrm{mg} / \mathrm{kg}$ ethanol extract of $\mathrm{R}$. vomitoria, $\mathrm{B}=200 \mathrm{mg} / \mathrm{kg}$ water extract of $R$. vomitoria $\mathrm{C}=5 \mathrm{mg} / \mathrm{kg}$ chloroquine (positive control), $\mathrm{D}=\mathrm{DMSO}$ (negative control).

Figure 1: Plate 1A-D: Curative assay photomicrographs of the sections of the $\times 200$, showing features of mice treated with $R$. vomitoria.

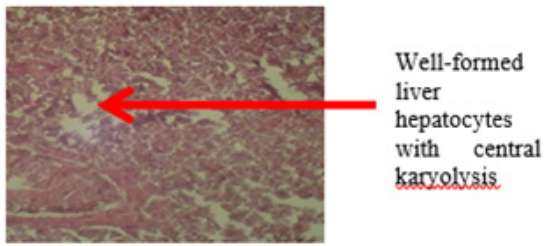

A

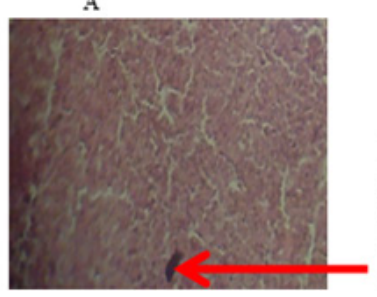

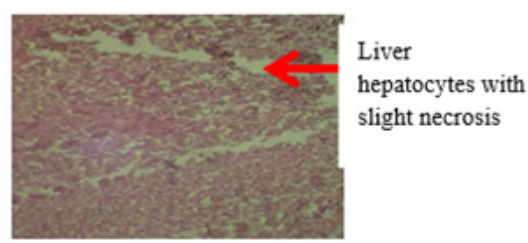

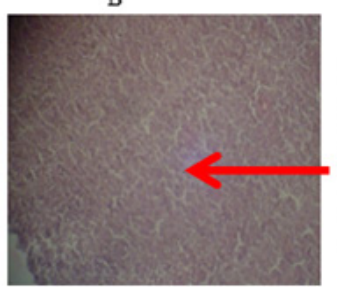

Unformed

hepatocytes with

greyish fibrous

cells over-

shadowing the

entire organ

Note: Keys: $\mathrm{A}=200 \mathrm{mg} / \mathrm{kg}$ ethanol extract of R. vomitoria, $\mathrm{B}=200 \mathrm{mg} / \mathrm{kg}$ water extract of $R$. vomitoria $\mathrm{C}=5 \mathrm{mg} / \mathrm{kg}$ chloroquine (positive control) $\mathrm{D}=\mathrm{DMSO}$ (negative control).

Figure 2: Plate 2A-D: Prophylactic assay photomicrographs of the sections of the $\times 200$, showing features of mice treated with $R$. vomitoria.

\section{Discussion}

The results of this study indicated that the water and ethanol extracts of $R$. vomitora produced a dose dependent chemosuppressive antimalarial activity. The chemo-suppressive activity against Plasmodium berghei was greater as the concentration of the plant extracts were increased. This indicates that antiplasmodial efficacy of plant extracts were dose dependent. The ethanol extract had higher chemo-suppression activity than the water extracts, this could be that ethanol extract contained more bioactive compounds which act as antiplasmodial agents. This corroborate the work of [22], the concentrations and proportions of the active compounds in plant extracts components depend on the solvent used in processing the plant. This result also showed that the plant extracts had a better chemo-suppressive activity for the prophylactic than the curative assay; this indicates that the plant extracts provide a better antiplasmodial efficacy when used as prophylaxis antiplasmodial drug. The percentage yield of the plant extracts using different solvents revealed that ethanol solvent gave the highest yield. [23] reported that alcohol is a better solvent for more consistent extraction of active substances against microbes from medicinal plants compared to other solvents. This may be due to the fact that ethanol is polar solvent and may be able to extract the bioactive ingredients without denaturing them. This agreed with the findings of [24], who reported that ethanol extract of some certain plants have higher phenolic and flavonoids when compared with the percentage yield of other solvents. This justifies the 
traditional use of alcohol in extracting the components of medicinal plants for application against pathogens [25]. The presence of phytochemicals is an indication that the plants contain bioactive components that might be responsible for the antiplasmodial properties of the extracts. This result is in accordance with the report of [26] and [27], who reported the presence of some phytochemical constituents in these plants.

The result of the biochemical assay that is, organ function indices showed that there was significant decrease in the level of biochemical parameters at lower concentration of extracts in the treated group compared to the untreated group, however, there was increase in the biochemical parameters at higher concentration as against the standard range of the parameters. This justify the study of [28-31] that the sudden elevation in the urea level and imbalance in the electrolytes level may be due to high concentration of plant extracts and malaria infection which could serve as indicators for kidney dysfunction. The histopathology results showed that the extracts exert some level of therapeutic effects on the infected mice compared to the untreated group which had unformed hepatocytes with greyish fibrous cells over-shadowing the entire organ. According to [17] which stated that infections that causes shrinking of the hepatocytes is toxic to the liver hepatocytes which result in the liver unable to perform its vital function of deamination and detoxification in the body of the host. The result obtained in this study however justifies the work of that administration of antimalarial drugs reduce the extent of damages caused by malaria parasite on the liver.

\section{Conclusion}

From the result of this study, it is evident that hot water and ethanol extracts of $R$. vomitoria possess antiplasmodial properties against Plasmodium berghei NK 65. Antiolasmodial efficacy of this extracts are dose dependent, however, ethanol extract showed higher antiplasmodial efficacy. Also, organ haematological indecies revealed that the extract could be toxic at higher concentration. The phytochemical and in vivo antiplasmodial activities of the studied plants indicate the rightful use by traditional healers. The presence of various phytochemical constituent in the extracts of the plants could be harnessed for developing and producing novel antimalarial drugs of natural source.

\section{References}

1. A Dey, JN De (2011) Ethnobotanical aspects of Rauvolfia serpentina (L) Benth ex Kurz in India Nepal and Bangladesh. J Med Pl Res 23(7): 212218.

2. DS Fabricants, NR Farnsworth (2001) The value of used in traditional medicines for drug discovery. Environ Health Persp 109(1): 69-75.

3. LE Ishaku, SB Francien, JM Lyndy, NE Jacobus (2017) The antibacterial activity of extracts of nine plant species with good activity against Escherichia coli against five other bacteria and cytotoxicity of extracts. BMC Comp Altern Med 17(5): 133-140.

4. K Saidu, A Onah, A Orisadipe, C Olusola, R Wambebe, et al. (2000) Antiplasmodial, analgesic and anti-inflammatory activities of the aqueous extract of the stem bark of Erythrina senegalensis. J Ethnopharmacol 71(7): 275-280.

5. JE Okokon, PA Nwafor (2009) Antiplasmodial activity of root extract and fractions of Croton zambesicus. J Ethnopharmacol 34 (121): 74-78.
6. G Philippe, L Angenot, P De Mol, E Goffin, M Hayette, et al. (2005) In vitro screening of some Strychnos species for antiplasmodial activity. J Ethnopharmacol 97(3): 535-539.

7. 00 Amole, AO Onabanjo, AA Odofin (2006) The analgesic effect of Rauvolfia vomitoria (Afzel). J Biomed Sci 17(5): 125-127.

8. OO Amole, OK Yemitan, KA Oshikoya (2009) Anticonvulsant activity of Rauvolfia Vomitoria (Afzel). Afr J Pharm Pharmacol 3(6): 319-322.

9. II Ezeigbo, MI Ezeja, KG Madubuike, DC Ifenkwe, IA Ukweni, et al. (2012) Antidiarrhoeal activity of leaf methanolic extract of Rauwolfia serpentina. Asian Pac J Trop Biomed 2(6): 430-432.

10. R Kutalek, A Prinz (2007) African Medicinal Plants. In: Yaniv Z \& U Bachrach (Eds.), Handbook of medicinal plants, New Delhi, India 4: 234.

11. S Sharma, JA Sommers, L Wu, VA Bohr, ID Hickson, et al. (2004) Stimulation of flap endonuclease- 1 by the Bloom's syndrome protein. J Biol Chem 279(11): 9847-9856.

12. RR Tomassini, LL Washington, BP Milena (2009) Effect of Seco-steriods purified from Physalis angulate on the viability of Leishmania species. J Antimicrob Chemo 6(4): 84-87.

13. AO Adeoye, CO Bewaji (2015) Therapeutic Potentials of Adansonia digitata (Bombacaceae) Stem Bark in Plasmodium berghei-Infected Mice. J Biol Sci 15(2): 78-84.

14. PJ Waako, P Smith, PI Folb (2015) In vitro interaction of Aspillia Africana (Pers), a traditional antimarial medicinal plant with Artemisin against Plasmodium falciparum. J Ethnopharmacol 102(6): 262-268.

15. Analytical Methods Committee (2002) Understanding and acting on scores obtained in proficiency testing schemes. Royal Society of Chemistry.

16. FJ Barker, MR Breach, P Chris (2006) Medical laboratory science, Chris Publisher, United Kingdom 3: 487.

17. M Cheesbrough (2014) District Laboratory Practice in Tropical Countries. $\left(2^{\text {nd }}\right.$ edn), Cambridge University Press, United Kingdom 6: 480.

18. RR Godse (2013) Hematological and biochemical evaluation in malaria patients with clinical correlation. Int J Res Rep Med Sci 3(4): 12-18.

19. Y Khatib, R Patel, K Sequeira, G Agrawal, N Chikhale (2015) Hematological and biochemical alterations in malaria and their correlation with Parasitic Index. IOSR J Pharm 9(5): 53-56.

20. MO Akanbi (2015) The influence of malaria infection on kidney and liver function in children in Akoko area of Ondo state, Nigeria. J Parasitol Vector Biol 7(8): 163-168.

21. P Jeruto, PF Arama, B Ayango, T Akenga, R Nyunja, et al. (2016) In vitro antifungal activity of methanolic extracts of different Senna didymobotryna (FRESEN). Afr J Trad Alt Med 13(6): 168-174.

22. MA Sonibare, TO Lawal, 00 Ayodeji (2011) Antimicrobial evaluation of plants commonly used in the management of psychosis opportunistic infections. Int J pharmacol 7(3): 492-497.

23. CP Anokwuru, I Esiaba, O Ajibaye, AO Adesuyi (2011) Polyphenolic content and antioxidant activity of Hisbiscus sabdariffa Calyx. Res J med Pl 5(5): 557-566.

24. K Pandit, RD Langfield (2004) Antibacterial activity of some Italian medicinal plants. J Ethnopharmacol 34(11): 102-111.

25. R Kumari, C Castilo, A Francesconi (2013) Agonist-dependent signaling by group I metabotropic glutamate receptors is regulated by association with lipid domains. Am Soc Biochem Mol Biol 8(56): 34-39.

26. LA Oseni, J Abgri, BK Sumabe, PJ Onilimor (2014) Leaf extracts of Vernonia amygdalina Del from Northern Ghana contain bioactive agents that inhibit the growth of some beta-lactamase producing bacteria in vitro. Br J Pharma Res 4(2): 192-202. 
27. JI Ebele, EN Emeka, CA Nnenna, CM Ignatius, A Ebele (2010) Malaria parasitaemia: effect on serum sodium and potassium levels. Int J Trop Med 5(67): 46-49.

28. UE Uzuegbu, CD Mordi, IS Ovuakporaye, OL Ewhre (2015) Effect of aqueous and ethanolic extracts of Tridax procumbens leaves on gastrointestinal motility and castor oil-induced diarrhea in wistar rats. Int J Nig Soc Exp Biol 27(1): 26-32.

29. JH Jasani, SM Sancheti, BS Gheewala, KV Bhuva, VS Doctor, et al. (2012) Association of electrolyte disturbances $(\mathrm{Na}+\mathrm{K}+)$ with type and severity of malarial parasitic infection. J Cl Diag Res 6(2): 678-681.
30. N Nwanchukwu, KN Agbafor (2011) Phytochemical analysis and antioxidant property of leaf extracts of Vitex doniana and Mucuna pruriens. Biochem Res Int 3(5): 21-27.

31. OT Soniran, OA Idowu, OL Ajayi, IC Olubi (2012) Comparative study on the effects of chloroquine and artesunate on histopathalogical damages caused by Plasmodium berghei in four vital organs of infected albino mice. J Malaria Res Treat 10(1): 1155-1162. 